\title{
Ukraine Dairy Market: State and Prospects of Development
}

\author{
Lyudmila Pronko ${ }^{1}$, Tatyana Kolesnik ${ }^{2}$, Oksana Samborska ${ }^{3}$
}

\begin{abstract}
The article discusses topical issues regarding the prospects for the development of the milk and dairy market. It is investigated that the largest breakthrough has been achieved by the dairy industry with milk, since DSTU 3662: 2018 "Cow's milk" came into force on January 1, 2019, the inflow of milk processing plants is not lower than the first grade, and it is known that private households provide largely only milk of the second grade. As a result, the quality and safety of milk purchased from industrial farms has increased significantly. The authors emphasize that an important factor in the development of production activity for producers is the selling price of milk, which in 2018 in Ukraine amounted to $7602,4 \mathrm{UAH} / \mathrm{t}$, which is $368,4 \mathrm{UAH} / \mathrm{t}$ more than in 2014.It is substantiated that there are a number of problems in the dairy industry of Ukraine that hinder its further development, the main ones being: increased competition from illegally operating enterprises, the shadow market, counterfeit products, lack of confidence and lack of cooperation between producers and processors of products, etc. The author has proved that these problems can be solved by combining milk producers and processors in cooperatives and providing them with effective state support.
\end{abstract}

Keywords: milk, dairy industry, quality, livestock, dairy cattle, selling price, market.

\section{Introduction}

The dairy industry is a leader in the food and processing industries. It includes enterprises for the production of animal oil, whole milk products, canned milk, dried milk, cheese, ice cream, casein, etc. (Hayduts'kyy: 2013). Milk and dairy products are nowadays one of the main valuable foods that are rich in protein, essential amino acids, trace elements, vitamins and other nutrients.

The production of milk and dairy products has its specific economic and organizational features: short shelf life of products in raw form, availability of a wide range of processing products, the need for cooperation and integration, due to the peculiarities of milk processing (Vasylchak: 2013).

In the formation of a complete cycle from the production of raw milk to the receipt of finished products to consumers, agriculture is in a difficult situation, primarily because of the large fragmentation of production (Hayduts'kyy, 2016). In most cases, the demand for final processing products is more flexible as to the demand for dairy raw materials.

| ${ }^{1} \mathrm{PhD}$ in economics, associate professor, Department of administrative management and alternative energy sources, Vinnytsia National Agrarian University, Ukraine.

${ }^{2} \mathrm{PhD}$ in economics, associate professor, Department of administrative management and alternative energy sources, Vinnytsia National Agrarian University, Ukraine.

${ }^{3} \mathrm{PhD}$ in economics, associate professor, Department of administrative management and alternative energy sources, Vinnytsia National Agrarian University, Ukraine. 
Formulating the goals. The purpose of the study is to substantiate the state of the dairy market in Ukraine and to determine its development prospects.

\section{Research}

Overall milk production statistics have deteriorated over the past five years: the national production shaft has decreased by $9.2 \%$, or about 1 million tons (Holovnuy sayt dlya ahrobiznesu Latifundist Media: 2017). In 2018, all categories of farms produced 10.064 million tons of milk, which is 216.5 thousand tons $(2.1 \%)$ less than last year. Households produced 7308.3 thousand tons, agricultural enterprises - 2755.7 thousand tons, which is respectively 206.5 and 10.0 thousand tons less than in 2017 . In 2014, the share of milk produced by households was $76.2 \%$, and that of agricultural enterprises was only $23.8 \%$. In 2018, the share of milk production by enterprises increased by $3.5 \%$ and reached $27.3 \%$, respectively, the volume of production in households decreased and equaled $-72.7 \%$ (Figure 1). Thus, the main producer of milk is still a private farm.

Analyzing the dynamics of milk production, we note that the volume of its production dependence on the period (month) and seasonality - in the summer, milk increases by 30-50\% (Holovnuy sayt dlya ahrobiznesu Latifundist Media, 2017...). The largest production of milk occurs in May-June, which is characterized by a period of growth of green mass, which in this period has a higher nutrition and useful qualities, which affects the productivity of livestock, and since July there is a decline in milk.

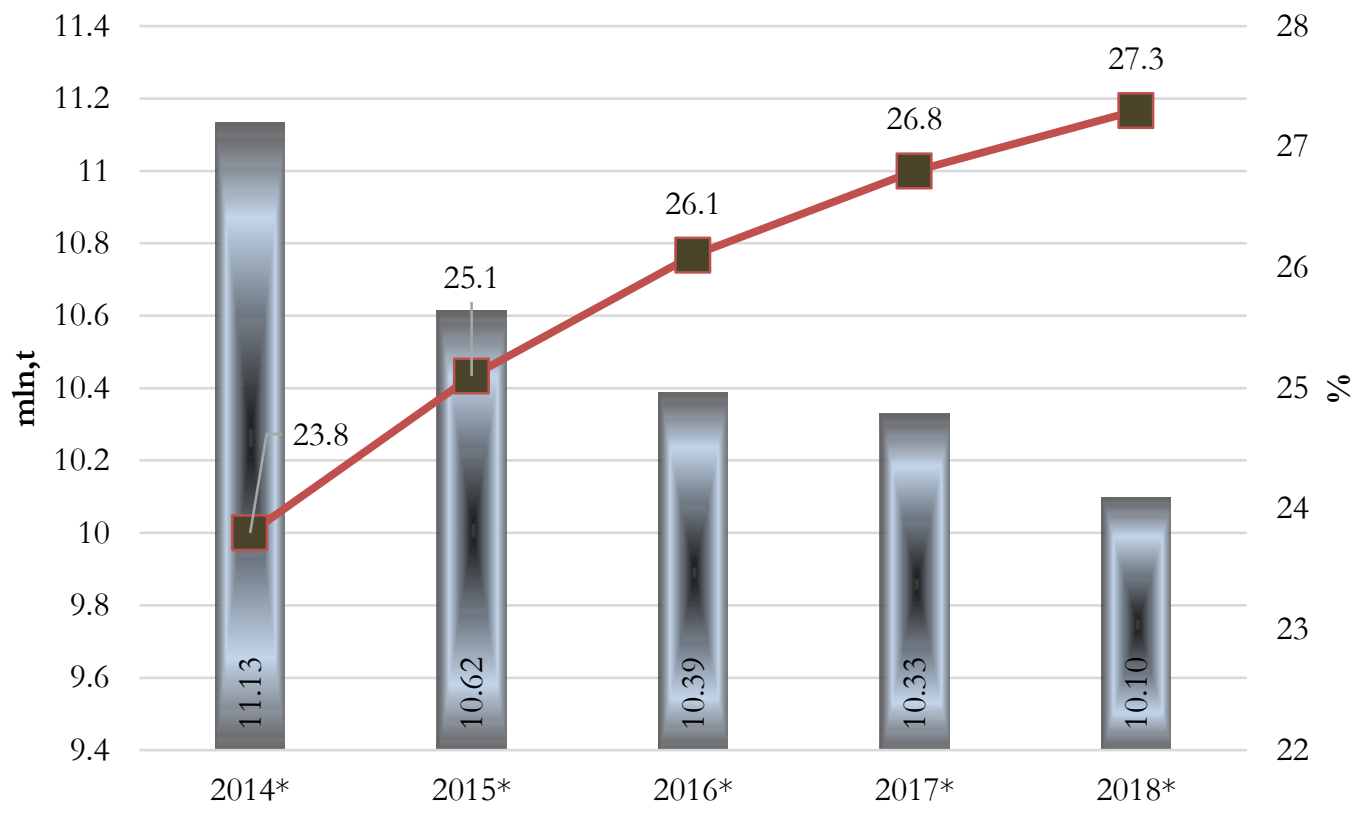

$\|$ Milk production, $\mathrm{mln} / \mathrm{t} \quad$ - Share of milk produced by agricultural enterprises

Fig. 1. Dynamics of milk production 
The volume of milk production depends on the livestock population and its productivity. Unfortunately, the total number of cows is decreasing every year, but their productivity is increasing due to the balance of the forage base, the development of breeding dairy cattle and the conditions of keeping.

As of January 1, 2019, in all categories of farms the number of cows was 1926.3 thousand heads, which is 91.5 thousand heads $(4.2 \%)$ less than in the corresponding period of the previous year. The share of cows in the households reached $75.7 \%$ (Fig. 2). During the analyzed period, the number of cattle in agricultural enterprises decreased by 1.14 million, in households - by 2.23 million. Thus, the number of cows in farms equaled 1.5 million heads, which is $3.3 \%$ less, than in 2017, and at enterprises - 467.9 thousand heads, which is $0.3 \%$ more than in 2017 .

This change is primarily due to the new milk quality requirements. Whereas, as of January 1, 2019, DSTU 3662: 2018 «Cow's milk» came into force, which stipulates that the milk processing establishments will receive not less than the first grade and, as we know, the farms provide largely the second-grade milk (Molochna surovuna korov yache, 2018...)

2.50

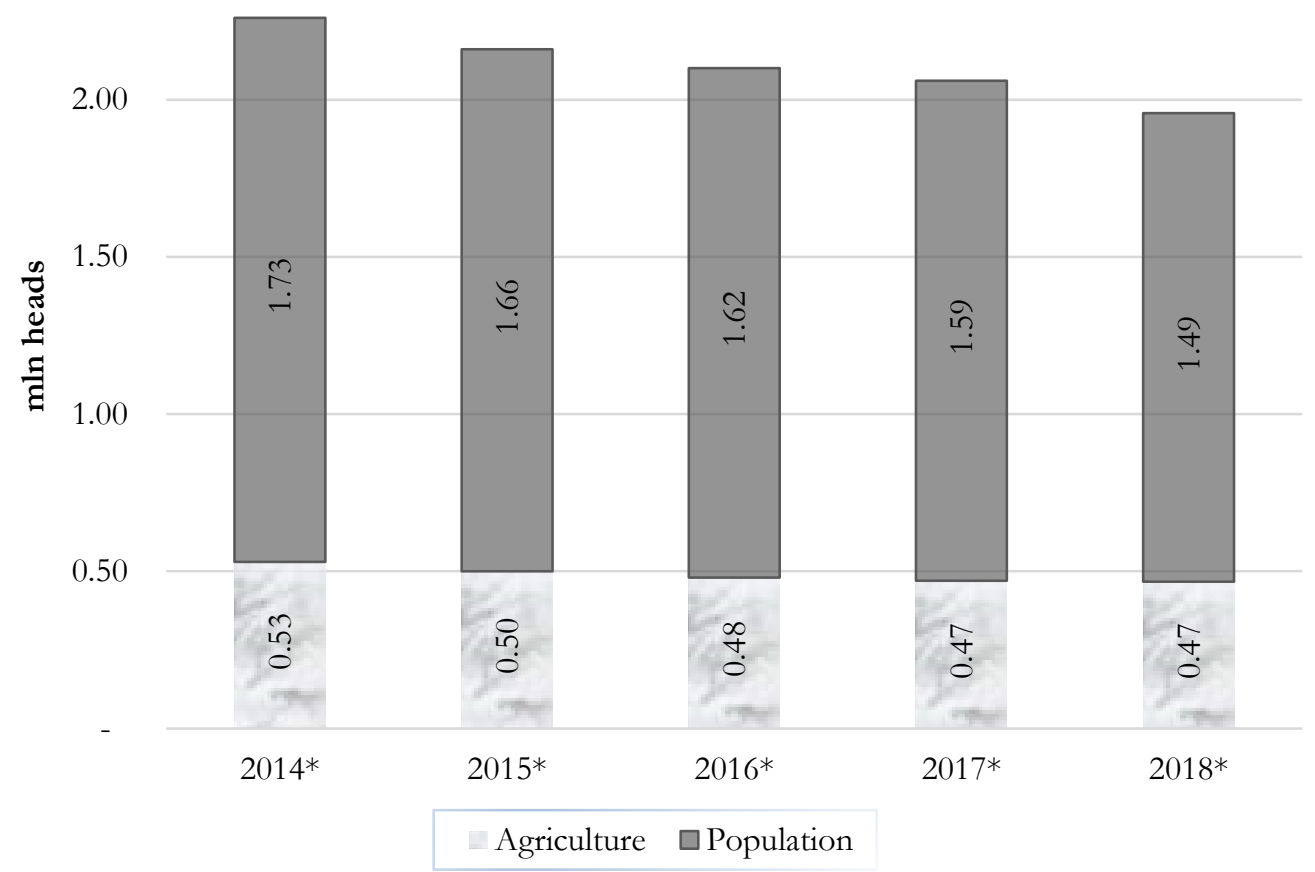

Fig. 2. Cows stock dynamics in 2014-2018, million heads.

Source: SSSU

As a result, dairies began to reduce the volume of milk intake from the private farms, because to bring it to high-quality condition, it is necessary to bear the additional costs of pasteurization, which, accordingly, will increase the cost. 
The main factor in stabilizing the situation in the dairy cattle industry is increasing the number of livestock and improving its productivity (Fig. 3).

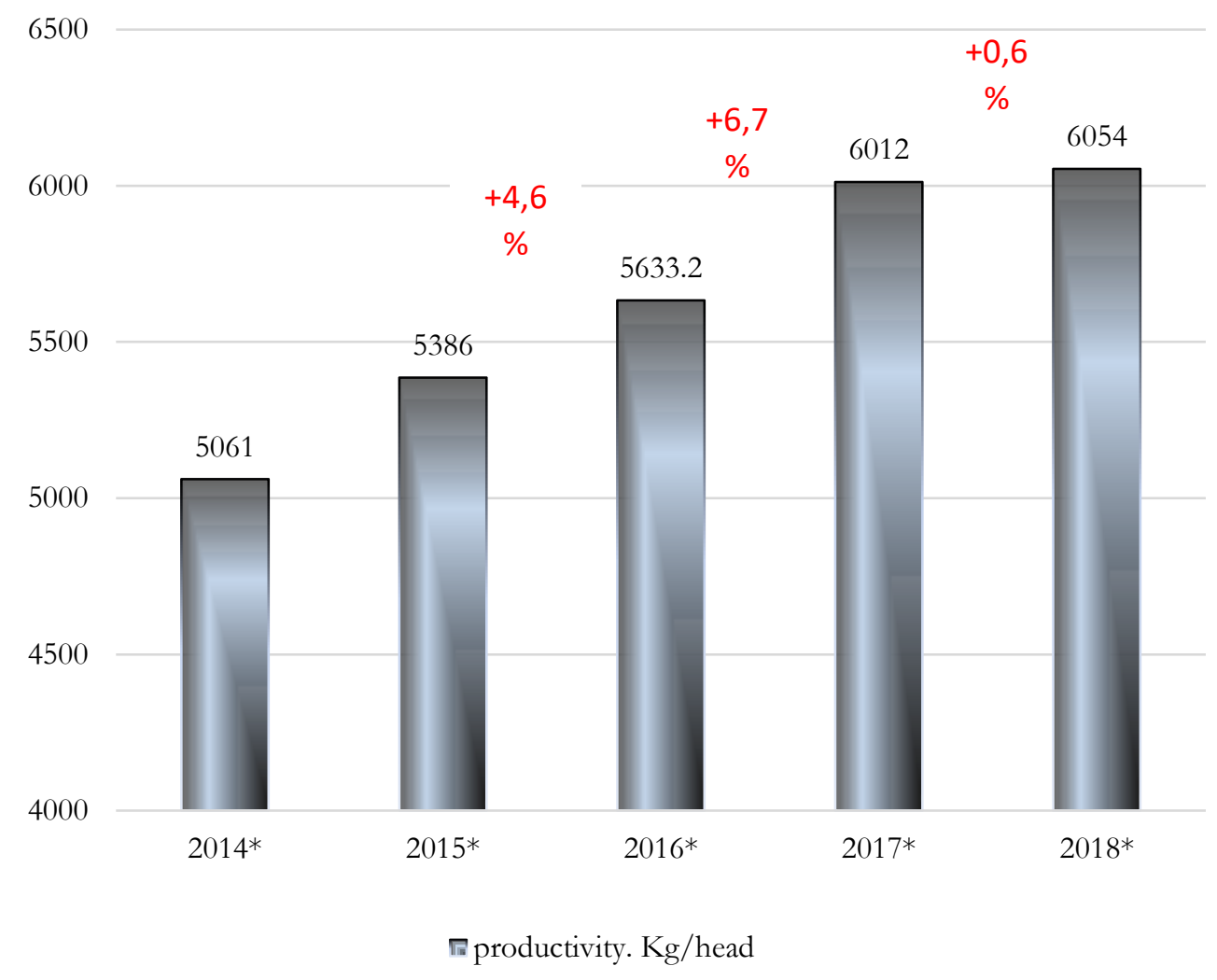

Figure 3. Dynamics of cow productivity in agricultural enterprises, $\mathrm{kg} / \mathrm{cow} / \mathrm{year}$

The productivity of cows is increasing every year. During the analyzed period, cow productivity increased by $19.6 \%$ and equaled $6054 \mathrm{~kg}$. The highest rate of productivity growth is seen in $2017-6.7 \%$ compared to $2016,5.6 \%$ reaching productivity growth in $2015,4.6 \%$ in $2016,0.6 \%$ in the reporting year. These positive changes are due to the intensification of production.

It should be noted that the negative dynamics of the decline in milk production was significantly influenced by the situation in households, since a larger share of livestock and poultry population is concentrated in households (reduced 92.8 thousand cows in households).

The biggest breakthrough domestic dairy industry has reached with milk. It is known that by 2019, there were five varieties of milk in Ukraine: extra, higher, first, second and non-varietal (Moloko-surovuna korov yache, 2018. DSTU 3662:2018 ...). The last two are characteristic of households. The most common in agricultural enterprises are the first, higher and extra. At the same time, all over the world, only milk is allowed to be processed in the world, which, according to the parameters of quality and safety, 
corresponds to the national extra-grade, the rest - not suitable for processing.

The share of extra and higher-grade milk has increased significantly over the last five years. The share of extra-variety in the structure of receipts for processing from agricultural enterprises increased from $9.2 \%$ to $21.6 \%$, and higher - from $33.8 \%$ to $38.1 \%$. The share of first-grade milk revenue decreased to $32.9 \%$ (Figure 4 ).

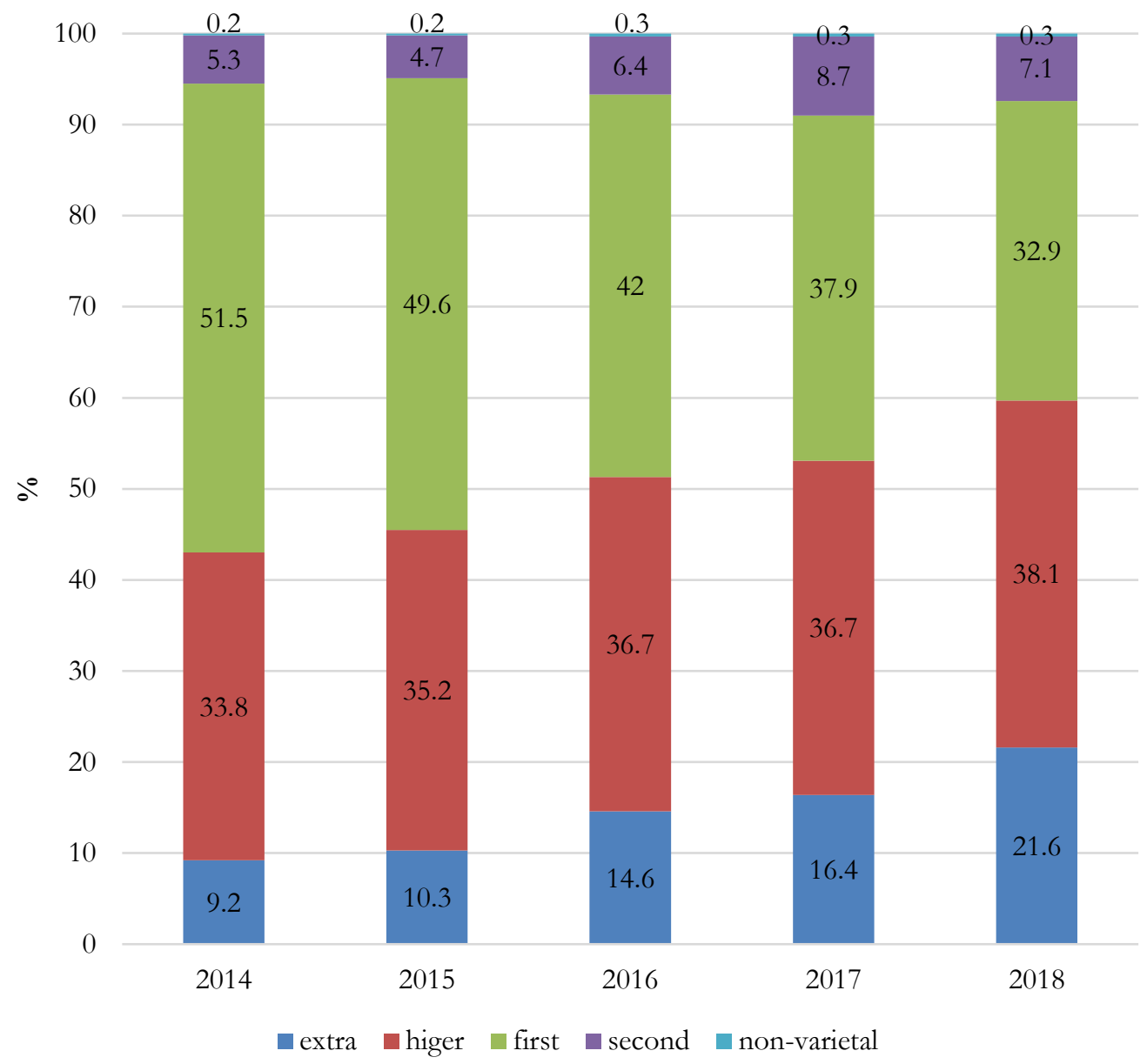

Fig. 4. Dynamics of milk quality, \%

Overall, according to the results of 2018, 4.18 million tons of basic fat milk was received by Ukrainian dairy enterprises, which is $3.9 \%$ less than in the corresponding period last year and $10 \%$ less than in 2014. Of the total raw material purchased from processing enterprises, 2.72 million tons of milk came from agricultural enterprises, which is $12.4 \%$ more than in 2014 and 1.09 million tons - households, which is 37\% less than the base year.

The quality and safety of milk purchased from farms is improving. Thus, the share of extra-grade in the overall structure increased to $21.6 \%$ and amounted to 586.2 thousand 
tons, higher grade - to $38.1 \%$ or 1.04 million tons, respectively, the share of volumes of milk of the first grade decreased by $42 \%$. It is worth to mention that $50 \%$ of all extragrade milk that goes into processing is provided by the dairy farmers' associations.

An important factor in the development of production activity for producers is the selling price of milk (Mostenska et. al., 2013) (Fig. 5).

Milk purchase prices in 2018 had a traditional seasonal fluctuation and were influenced by global trends. As a consequence, the average price for milk did not exceed $\$ 30 / 100$ $\mathrm{kg}$ ECM (fat $-4 \%$, protein $-3.3 \%$ ). At the same time, the average indicative price for milk calculated by the German experimental network IFCN was $\$ 34.1 / 100 \mathrm{~kg}$.

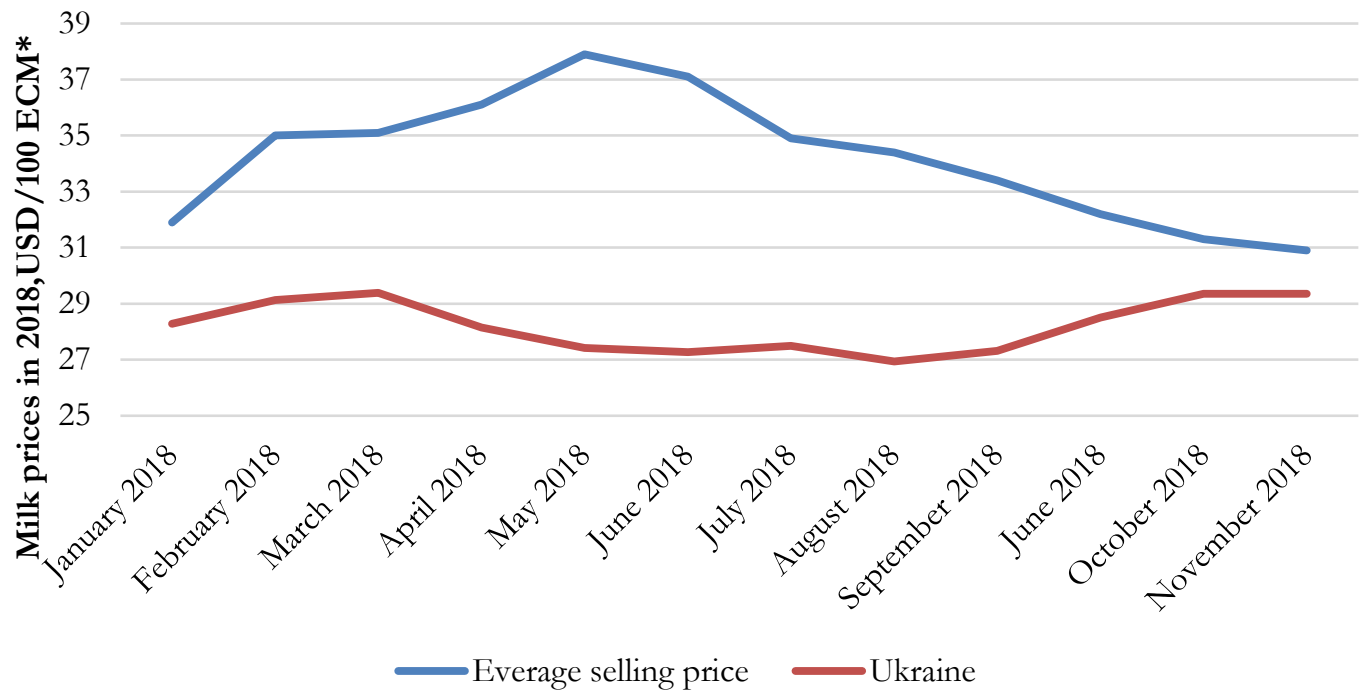

Fig. 5. Milk. prices in 2018, USD / $100 \mathrm{~kg}$ ECM *

* Energy-adjusted ECM milk (fat-4\%, protein-3.3\%)

Source: AVM calculations

The average selling price of milk in Ukraine in 2018 was 7602,4 UAH / t, which is 368,4 UAH / $\mathrm{t}$ more than in 2014. According to the data of the regions, as of 04.01.2019 the purchase prices of milk of I grade without VAT increased by $2 \%$ and amounted to 8.71 UAH / kg, the wholesale and selling price of milk of $2.5 \%$ fat content in the film increased by $8 \%$ and equaled $6.08 \mathrm{UAH} / \mathrm{kg}$, butter - 9\% - $129.76 \mathrm{UAH} / \mathrm{kg}$.

However, purchase prices for milk of II grade without VAT decreased and equaled 6.93 $\mathrm{UAH} / \mathrm{kg}$, for milk of II grade from households - $5.06 \mathrm{UAH} / \mathrm{kg}$.

According to the Ministry of Finance of Ukraine, the consumer price index for milk in January 2019 was $100.20 \%$.

For any industry or market, trade remains the key driver of development. In JanuaryDecember 2018, according to DFS data, milk and milk imports in terms of milk reached 181.4 thousand tons, which is $38.1 \%$ more than in the corresponding period of 2017, exports amounted to 789.7 thousand tons, up 1.3\% from 2017 (Table 1).

In the process of reaching projected figures, there are options that best meet the 
potential for increased production.

Table 1: Exports and imports of dairy products in January-December 2018 (in terms of milk)

\begin{tabular}{|c|c|c|c|c|}
\hline \multirow[t]{2}{*}{ Product } & \multicolumn{2}{|l|}{ Export } & \multicolumn{2}{|l|}{ Import } \\
\hline & tons & $\begin{array}{l}\text { Changes as to } \\
\text { previous year }\end{array}$ & tons & $\begin{array}{l}\text { Changes as to } \\
\text { previous year }\end{array}$ \\
\hline Milk and cream not condensed & 20815 & $+48,0 \%$ & 1326 & $+58,4 \%$ \\
\hline Milk condensed and dry & 44320 & $-24,1 \%$ & 6103 & $+38,6 \%$ \\
\hline Yoghurts & 7658 & $+47,4 \%$ & 6800 & $+34,5 \%$ \\
\hline Serum & 3194 & $\begin{array}{l}\text { On the previous } \\
\text { year average }\end{array}$ & 210 & $+51,6 \%$ \\
\hline Butter & 607660 & $-0,2 \%$ & 21980 & $+46,3 \%$ \\
\hline Cheese & 87602 & $-7,8 \%$ & 144081 & $+37,1 \%$ \\
\hline Ice cream & 18444 & $+21,3 \%$ & 888 & $+12,5 \%$ \\
\hline
\end{tabular}

Considering these conditions, the factors that determine export potential are the volume of domestic production and its quality, purchasing power of the population, the ratio of prices in the domestic and foreign markets, quotas or other restrictive factors, including veterinary and sanitary restrictions. Tariff quotas for agrarian products provided to Ukraine within the framework free trade zone with the EU in 2018 for milk, cream and yogurt - 8000 tonns /years, cheeses of all kinds - 2000 tonns /years (Tetiana Kolesnyk, Oksana Samborska et. al., 2018).

At the same time, it should be noted that farmers, not only in Ukraine but also in the whole world, had problems with prices [9]. Excessive milk on the global market and high prices for feed and oil have led to the loss of many farmers in Europe, Oceania and the United States. Thus, the average purchase price in Europe dropped by $2.4 \%$ per year, in New Zealand - by $8.5 \%$, and in the US - by $12 \%$.

According to the FAO forecast, milk production is expected to grow by $2.1 \%$ in 2018 , mainly due to the growth of its production in Asia, including India, which is one of the largest producers in the world and the Philippines.

Asia accounts for the largest share in world milk production (40\%), Europe ranks second in overall structure - 27\%, followed by North America (13\%), South America (8\%), Africa $(6 \%)$ and Oceania $(4 \%)$. Asia is also the largest importer of dairy products, accounting for almost $60 \%$ of world dairy imports, and the largest exporters are Europe $(36 \%)$ and Oceania (30\%).

Table 2: Some indicators of the functioning of the global dairy market according to the FAO 2018 report, (thousand tons, in terms of milk)

\begin{tabular}{|l|l|l|l|l|l|l|l|l|l|}
\hline & \multicolumn{3}{|l|}{ Production } & \multicolumn{2}{l|}{ Import } & \multicolumn{2}{l|}{ Export } \\
\cline { 2 - 10 } & $\begin{array}{l}2014- \\
2016 \mathrm{p}\end{array}$ & $2017 \mathrm{p}$ & $2018 \mathrm{p}$ & $\begin{array}{l}2014- \\
2016 \\
\mathrm{p}\end{array}$ & $\begin{array}{l}2017 \\
\mathrm{p}\end{array}$ & $2018 \mathrm{p}$ & $\begin{array}{l}2014- \\
2016 \\
\mathrm{p}\end{array}$ & $2017 \mathrm{p}$ & $2018 \mathrm{p}$ \\
\hline Asia & 314197 & 323470 & 333153 & 40650 & 42327 & 43938 & 6528 & 6203 & 6029 \\
\hline
\end{tabular}




\begin{tabular}{|l|l|l|l|l|l|l|l|l|l|}
\hline Africa & 45759 & 45080 & 45516 & 10380 & 9836 & 10407 & 1275 & 1190 & 1189 \\
\hline $\begin{array}{l}\text { Central } \\
\text { America }\end{array}$ & 17189 & 17556 & 17710 & 5349 & 6111 & 6368 & 763 & 1440 & 1450 \\
\hline $\begin{array}{l}\text { South } \\
\text { America }\end{array}$ & 63459 & 63473 & 64824 & 3202 & 3199 & 3026 & 4262 & 3259 & 3332 \\
\hline $\begin{array}{l}\text { North } \\
\text { America }\end{array}$ & 103581 & 107182 & 109193 & 2629 & 2604 & 2543 & 10511 & 11779 & 12462 \\
\hline Europe & 220514 & 224400 & 227089 & 6849 & 6320 & 5694 & 24478 & 26251 & 26842 \\
\hline Oceania & 31516 & 30710 & 31040 & 1230 & 1521 & 1570 & 22541 & 21622 & 22244 \\
\hline Total & 796215 & 811870 & 828524 & 70289 & 71918 & 73546 & 70359 & 71744 & 73549 \\
\hline
\end{tabular}

Source: FAO data (Holovnuy sayt dlya abrobiznesu Latifundist Media: TOP-10 proyzvodyteley molochnoy y molokosoderzhashchey produk.tsyi 2017. URL: https: / latifundist.com/ rating/top-10-proizvoditelej-molochnoj-imolokosodershash chejproduktsii-2017)

Looking at the manufacturers of finished goods, the largest exporters of CCS are New Zealand (56\%), EU (16\%), Argentina (3\%) and Uruguay (4\%), SCM - EU (33\%), USA $(27 \%)$, New Zealand (16\%) and Australia (7\%), butter - New Zealand (50\%), EU (21\%), Belarus ( $9 \%$ ), USA (4\%) and Ukraine (4\%), cheese - EU (33\%), the United States (14\%), New Zealand (14\%), Belarus (7\%), Australia (7\%) and Egypt (4\%).

Studying the experience of leading foreign countries, we can identify specific areas of state regulation of the market of milk and dairy products [10;5]:

regulation of prices for milk and raw materials control of consumer prices, direct payments to producers, regulation of milk sales by agricultural producers, regulation of economic mechanism in the agricultural sector, support for innovative developments.

Production volumes are regulated by setting quotas for the production of certain types of products, changing specialization, withdrawal of agricultural land. In most countries, the regulation of farmers' incomes and prices for agricultural products is monitored by changes in some economic indicators. These can be costs by type of production (USA) or by groups of specialized farms (EU), price parity for agricultural products and means of production for agriculture, profitability of certain sectors of the economy.

In the advanced market economies, dairy companies have been consolidating in recent decades through mergers of small and large international companies, which has led to the consolidation and specialization of dairy farms. The economic basis of these processes is cooperation and integration. State control aims at large integrated formations that provide less costs and greater production efficiency when interacting with farmers (Pyankova, 2014).

The market of milk and dairy products in most foreign countries is one of the most regulated (Stepanchuk et al., 2017). Specific areas of government influence are milk price support programs, milk marketing regulations, cooperative price regulation, import regulation, government commodity and purchasing interventions, milk quotas, direct payments to producers, support for innovative developments, etc. 


\section{Conclusions}

Taking into consideration the mentioned above, we can say that in the dairy industry of Ukraine there are a number of problems that hinder its further development, namely:

- Constant misunderstandings and mistrust between milk producers and processors, almost no cooperation - both parties are trying to increase their own profits at the expense of the other. Instead of cooperating and developing together, manufacturers and processors cannot agree on each other. Milk producers demand a rise in prices for dairy raw materials during their seasonal decline (November-February). In turn, dairies are trying to get the highest possible price during the "big milk" period. However, milk producers have been more successful in this. Last but not least, by joining national and regional associations that lobby their interests and synchronize their work.

- Concentration of milk production in private farms is the main reason for the low quality of milk and, consequently, the products of its processing. In modern conditions, households are unable to provide high quality milk for a variety of reasons: noncompliance with requirements for keeping cows, violations of sanitary and hygiene standards and, as a consequence, high bacterial contamination of milk, breach of milking technology, no conditions for cooling milk, violations of requirements for milk storage, there is no possibility of immediate transportation of milk to dairies - the absence of «cold logistics» - significantly complicates the state's control over the quality of milk.

- Insufficient control by the quality control authorities of the dairy products produced The quality of dairy products depends directly on the quality of the raw materials from which they are produced. The quality of raw materials, in turn, depends on the manufacturers adherence to established norms and standards during production. Dairy processors have no mechanisms to influence producers, as most of the year there is a shortage of milk on the market. This leads to violations of many production standards, especially in the private farms of the population.

- Increased competition from illegally operating businesses, the shadow market, counterfeit products - Recently, small dairies have appeared in almost every district, operating without mandatory permits and even state registration. They collect milk for cash at higher prices, produce dairy products (mostly soft and sour milk cheeses) and sell it for cash. They do not pay taxes and do not meet any production standards. This, in turn, also contributes to the poor quality of the raw material, because manufacturers know that if the plant does not accept poor quality raw materials, it will be taken over by illegally operating enterprises. As a result, legally operating dairy companies suffer from unfair competition, local budgets from under-revenues, and consumers who are at risk of consuming poor-quality products.

- Low technological level in production facilities, lack of modern equipment - recently in almost every district there have been small dairies operating without mandatory permits and even state registration. They collect milk for cash at higher prices, produce dairy products (mostly soft and sour milk cheeses) and sell it for cash. They do not pay taxes and do not meet any production standards. This, in turn, also contributes to the poor quality of the raw material, because manufacturers know that if the plant does not accept poor quality raw materials, it will be taken over by illegally operating enterprises. As a 
result, legally operating dairy companies suffer from unfair competition, local budgets from under-revenues, and consumers who are at risk of consuming poor-quality products.

- Lack of qualified management and inconsistency of future specialists with the requirements of the industry - for the last 20 years universities have not updated the material and technical base. In addition, outdated technology is taught to students now. But dairy science and production have gone a long way! So now there are not enough high-quality dairy technologists. In addition, it is very important to qualify the so-called average production line - the head of the workshop, technologists, craftsmen, who ensure the stability and reliability of production. The high qualifications of these people make it easier for the top executives of companies and more.

As a result of the identified problems, we suggest:

- unite milk producers and processors in cooperatives;

- introduce identification and registration of cattle that would meet the requirements of the European market;

- to ensure systematic and effective state financial support for milk producers;

- to modernize milk production on the basis of new technologies.

So, as the global food crisis and agricultural commodities are becoming more and more valuable in the world, Ukraine with its favorable climatic conditions and investment

\section{References}

Belinska N., Lesko O. (2012). Economical efektyvn'ist diyalnosti molokopererobnuh ta transformatsiynuh protsesiv v Ukraine: Monohrafiya. Vinnitsia, VNTU. 2012. p.280.

Vasylchak S.V. (2013). Osobluvosti funksionuvan'a runky moloka ta molochnoyi produktsiyi, 15. Kiev, Naukovuy visnuk NLTU Ukraine. 2013. Pp. 357-362.

Hayduts'kyy P.I. (2016). Agrarna reforma in Ukraine. Kiev, 2016. P. 424.

Holovnuy sayt dlya ahrobiznesu Latifundist Media: TOP-10 proyzvodyteley molochnoy y molokosoderzhashchey produktsyi 2017. Retrieved from https://latifundist.com/rating/top-10proizvoditelej-molochnoj-i-molokosoderzhash chejproduktsii-2017.

Dzhedzhula V.V., Yepifanova I.Y., Dzyubko M.Y. (2018). Napryamu pidvyshchennya efektyvnosti diyal'nosti pidpryemstv molochnoi galuzi Investytsiyi: praktyka ta dosvid, 11. Pp.12-14.

Keranchuk T.L. (2017). Molochna haluz Ukraine: perspektivu i problemu rozvutku. Shidna Europa: Economika, biznes ta upravlin'a, 3(08). Pp.133-136.

Moloko-surovuna korov`yache. (2018). DSTU 3662:2018 from 27.06.2018. Tekhnichni umovu.

Kolesnyk T.V., Samborska O.Yu. (2018). Ensuring the sustainable development of Ukrainian agrarian sector in conditions of globalization. Problems and Perspectives in management. Volume 16. Issue 3.pp. 245- 258.

Mostenska T.L., Sychevkyy M.P. (2013). Vpluv cinu na konkurentospromozhnist'i produktsiyi na runku moloka. Naukovi pratsi. National unstitute harchovuh tehnologiy, 52. Pp.165-175.

Ofitsiynuy sayt Derzhstat Ukraine. Retrieved from http:www.ukrstat.gov.ua.

Pyankova O. V. (2014). Obgruntuvanya napryamiv rozvutku tovarnuh portfeliv pidpriemstv molochnoyi promyslovosti do zahal'nosvitovuh ta Ukraine tendentsiy spozhyvchoyi povedinku. Formuvannya rynkovykh vydiv v Ukrayini. Zbirnuk naukovuh prats', 2. Pp.89-95.

Stepanchuk S.O., Yefisko Y.U. (2017). Stan ta perspektuvu rozvutky molochnoho runku Ukraine. Economika ta derzava, 5. Pp. 99-102.

Tyvonchuk S.V., Tyvonchuk Y.O., Pavlotska T.P. (2017). Rozvutok runky vurobnytstva moloka v Ukraine v konteksti yevrointehratsiynykh protsesiv. Kiev, Economika APK, 4., pp. 25-31. 